\title{
Design and Validation \\ of the Cooperative Learning Application Scale (CLAS)
}

\author{
Cristina Atxurra, Lourdes Villardón-Gallego, and Esther Calvete \\ University of Deusto
}

\begin{abstract}
In this study, a scale was designed to measure the level of application of Cooperative Learning in Higher Education. The Cooperative Learning Application Scale (CLAS) comprises seven dimensions: Positive interdependence, interaction, social skills, group reflection, heterogeneity, assessment and tutoring. The sample consisted of a total of 1470 students from two Universities: the University of Deusto (Spain) and the Catholic University of Temuco (Chile). The results show that CLAS is a valid and reliable tool to gauge the level of application of this methodology in university classrooms.
\end{abstract}

Keywords: Cooperative learning, higher education, validation, scale, group work.

\section{Resumen}

En este estudio se diseñó una escala para valorar el grado de aplicación del Aprendizaje Cooperativo en la Universidad (CLAS). El instrumento consta de 7 dimensiones: Interdependencia positiva, interacción, habilidades sociales, reflexión grupal, heterogeneidad, evaluación, y tutoría. La muestra estuvo formada por un total de 1470 estudiantes de dos Universidades: la Universidad de Deusto (España) y la Universidad Católica de Temuco (Chile). Los resultados obtenidos muestran que el CLAS es un instrumento válido y fiable para conocer el grado de aplicación de esta metodología en las aulas universitarias.

Palabras clave: Aprendizaje cooperativo, enseñanza universitaria, validación, escala, trabajo grupal.

Correspondence concerning this article should be addressed to Cristina Atxurra, Department of Teaching and Curriculum Development. University of Deusto, Apdo. 1, 48080 Bilbao (Spain), telephone number: 0034944139000 (ext. 2214), fax: 003494 4139089. E-mail: cristina.achurra@deusto.es 


\section{Introduction}

Teamwork is a generic competence that facilitates adaptation to fast changes in society and the world market (Vargas, 2006). Being able to integrate and contribute to group work is essential. Thus, teamwork has become one of the most demanded competences on the labor market (Aguado, Arranz, ValeraRubio, \& Marín-Torres, 2011; Ayats, Zamora, \& Desantes, 2004) and hence, an essential element of employability (Barraycoa \& Lasaga, 2010).

Cooperative Learning (CL) is a learning methodology centered on the student. When applied effectively, it favors development of teamwork competences that will help in professional and social life. For this reason, many authors recommend including it in any training program, regardless of the certification or organizational context in which it is set (Biggs \& Tang, 2011; Cavanagh, 2011; Hammond, Bithell, Jones, \& Bidgood, 2010; Zubimendi, Ruiz, Carrascal, \& de la Presa, 2010).

In general, CL can be understood as a generic term used to refer to several techniques for organizing and conducting classroom instruction in small, heterogeneous groups in order to achieve common learning goals (Johnson, Johnson, \& Holubec, 1994; Slavin, 1990). Hancock (2004, p. 160) defines it as "students working in mixed-ability groups on clearly defined tasks with the expectation that they will be rewarded on the basis of group success".

Cooperation implies necessary teamwork. However, interacting is not enough to collaborate; it is the nature of this interaction that defines cooperation. The success of cooperative activities does not occur automatically by grouping students, a teaching design that considers the conditions for cooperation are necessary (Gillies \& Boyle, 2010; Ovejero, 1990; Peterson \& Miller, 2004; Prieto, 2007).

The level of effectiveness of CL depends on how teachers guarantee the conditions of cooperation. It is important, firstly, to understand what it means to work cooperatively and, secondly, to be capable of conducting cooperative activities that allow them to improve the quality of their students' group work (Blackford, Kutnikm, Baines, \& Galton, 2003; Gillies \& Boyle, 2010).

Leading scholars in CL, including Johnson, et al. (1994), Kagan \& Kagan (1994) and Cohen (1994), pointed out a series of considerations that teachers must take into account when implementing CL. According to their contributions, teachers should be able to achieve the following when applying cooperative learning:

Positive Interdependence entails the perception by all group members that they cannot achieve their goals by themselves if the others do not achieve theirs. Teachers must design and communicate the ob- 
jectives and tasks to students, so that they understand that the efforts of each team member are essential to the success of the group. Every member must have responsibilities in the communal project.

Interaction refers to an active learning environment where all students help and support each other. Teachers must create a climate and atmosphere that promotes communication, so that members can express their ideas and feelings in their group.

Social Skills are necessary for the success of the cooperative group. Skills can be divided into those geared towards the achievement of the group task and those focused on interpersonal relations. These skills are needed to make decisions, build trust, communicate appropriately, help each other, solve conflicts, organize efficiently, etc.

Group Reflection entails the joint assessment by group members of the learning process being carried out. This reflection improves their awareness of the group's strengths and weaknesses, as well as their progress and setbacks, and allows them to take action for correction and improvement.

Heterogeneity is related to the in-group level of diversity regarding skills, academic level, sex, ethnicity, interests, motivations, etc. This diversity enables students to consider and value different perspectives and points of view.

Teachers have two main tools to achieve these dimensions: Assess- ment, which has to do with issues related to information, equity, and fairness of the evaluation system at both the individual and group level. Foremost, the evaluation system is key to the necessary conditions for cooperation. Lastly, tutoring refers to the support provided by the teacher in order to foster the development of the group task. Teachers must plan and structure the learning sequence, make sure that the students know and understand the task, monitor the process and observe the students, helping them if needed. Tutoring must foster the autonomy for learning.

A review of previous research has found no appropriate tools that measure the level of application of CL in university classrooms taking into account the dimensions described.

However, some studies did use tools that considered some of the elements of CL. Prominent among them was Classroom Life Instrument (CLI), by Johnson, Johnson, and Anderson (1983), whose scale contained 59 items, of which 7 refer to CL in general, 10 to positive interdependence, 5 to assessment, and 8 refer to support provided by the teacher, which would relate to the tutoring dimension. In a subsequent second version of this tool, the heterogeneity dimension was included (see Johnson \& Johnson, 1983). Nevertheless, it did not include significant dimensions such as group reflection, interaction or social skills. Although these instru- 
ments were designed for a non-university sample, Ghaith (2002) used the second version of the CLI with university students, but his research failed to provide information about reliability and validity of the instrument.

Also prominent were Quality of Cooperative Learning (QCL) and Conditions for Cooperative Learning (CCL), created by Hijzen, Boekaerts, and Vedder (2006) for high school students. QCL comprises 4 subscales, two of which are related to the CL dimensions of interdependence and social skills, while the other two are attitudes toward $A C$ and quality of group cohesion. On the other hand, CLL includes a subscale related to the teacher's behavior regarding CL and two subscales related to the teacher's tasks of providing academic support and encouragement, which would relate to the tutoring dimension. Therefore, these instruments do not gather information about dimensions such as group reflection, interaction or heterogeneity.

Other instruments include items related to group work attitudes and group work organization, that is, they are not aimed at determining the conditions for cooperation.

That is the case of the Cuestionario de Análisis de la Cooperación en Educación Superior (ACOES) by García, González, and Mérida (2012), a tool created ad hoc, with 49 items through which the following dimensions are measured: Conception (idea) of group work, util- ity, planning of the group work by the teachers, criteria for the organization of groups, group rules, internal procedures, and efficiency of group work.

The Autoinforme de Interacción Grupal (AIG) by Ibarra and Rodríguez (2007) focuses on the quality of university students' group interaction. The instrument includes nine dimensions: Exploratory questions, cumulative reasoning, conflict management, group composition, task features, processes and procedures, individual and group motivation, performance evaluation and general conditions. The dimensions of both instruments, the ACOES and the AIG, are only indirectly related to the elements mentioned in this paper.

Only one tool has been found which includes nearly all the dimensions: Cooperative Learning Observational Schedule (Veenman, Benthum, Bootsma, Dieren, \& Kemp, 2002) which measures, through a 23-item observational scale, the manner in which teachers structure CL. It comprises 7 categories: Positive interdependence, individual responsibility, interaction, social skills, group processing, workgroup monitoring, and pupil engagement rates. However, this instrument was designed for assessment of the level of implementation of the $\mathrm{AC}$ to be carried out by an outside observer rather than the students.

The structure of all of the above instruments was validated through confirmatory analysis except 
the Cooperative Learning Process Scale (CLPS) by Bay \& Çetin (2012). However, this instrument does not include important aspects such as assessment, tutoring or heterogeneity.

To sum up, the majority of the instruments mentioned not only fail to include all the essential elements of this methodology, but neither have they been validated through confirmatory factor analyses of the theoretical model of the construct. Therefore, there is a need to provide an instrument that measures, in a valid and reliable manner, the degree of application of CL in Higher Education.

This paper aims to develop and validate an instrument to measure the degree of application of CL in Higher Education, on the basis of the essential theoretical elements of CL. The expected results were the following: CL would be explained by 7 factors (positive interdependence, interaction, social skills, group reflection, assessment, heterogeneity and tutoring).

\section{Method}

\section{Participants}

The sample consisted of a total of 1470 students from two different Universities. $53.3 \%$ were enrolled at the Catholic University of Temuco (Chile) and $46.7 \%$ were enrolled at the University of Deusto (Spain).
Specifically, the Catholic University of Temuco sample, was formed by 406 women $(51.8 \%)$ and 280 men $(35.7 \%)$. $12 \%$ of the students did not respond to the question related to gender. The students' mean age was 20.53 years $(S D=2.42)$, with a minimum value of 17 and a maximum of 29 years. Concerning their year of study, $49.1 \%$ were first year students, $14.8 \%$ were second year students, $10.2 \%$ were in their third year, $21.6 \%$ were fourth year students and $1.5 \%$ were fifth year students. $2.8 \%$ were enrolled in optional subjects, not pertaining to any specific academic year.

At the University of Deusto, the sample consisted of 406 women $(59.2 \%)$ and 280 men $(40.8 \%)$. The students' mean age was 21.23 years $(S D=3.47)$, with a minimum value of 18 and a maximum of 59 years. As per their year of study, $29.3 \%$ were first year students, $20.7 \%$ were second year students , $19.4 \%$ were in their third year, $26.5 \%$, were fourth year students and $5.1 \%$ were fifth year students.

\section{Measures}

Cooperative Learning Application Scale (CLAS) was elaborated by the students. It was elaborated by the authors of this paper to measure the degree of cooperation promoted by the lecturer, based on the core elements of cooperation. 
In order to ensure the validity of content, the first version of the questionnaire was reviewed and judged by 8 experts on research and didactics (6 Spanish and 2 Chilean). Using a table designed for the purpose, the experts had to indicate the dimension to which each item belonged, according to its content, as well as the degree of clarity of its wording. They also were allowed to suggest improvements. Only those items valued as "well expressed" by 6 out of the 8 experts and included in the same dimension by 6 out of 8 judges were kept.

Thus, the CLAS was finally made up of 44 items grouped into 7 dimensions (positive interdependence, interaction, social skills, group reflection, heterogeneity, assessment and tutoring). A Chilean expert reviewed the language of this version in order to adapt the wording of the items to the Chilean population and context.

Students were asked to establish their degree of agreement with the assertions using a 4-point Likert scale (from 1 "strongly disagree" to 4 "strongly agree"). The total application of the CLAS dimensions was calculated by the average scores of the items in each of the dimensions. Hence the range is 1-4. The Appendix includes the complete questionnaire.

\section{Procedure}

In order to choose the participants, lecturers from both univer- sities were contacted. All of them used methodologies based on group work for their subjects. They were informed of the goals of the study and asked to collaborate in order to apply the instrument to the students in their subjects.

A total of 71 teachers voluntarily agreed to participate in the study, 45 teachers $(63.4 \%)$ from the University of Deusto and 26 teachers $(36.6 \%)$ from the Catholic University of Temuco, which resulted in 71 different groups of students. Each group was visited by a person who provided the students with information about the research and requested their voluntary collaboration. The scale was applied collectively in about 15 minutes.

\section{Data analysis}

The CLAS was subjected to different analyses. In order to determine the degree of application of Cooperative Learning according to the students in the 71 groups taking part in the study, descriptive analyses were carried out. The internal consistency of the scale was calculated with Cronbach's Alpha and the Split-Half Method.

In order to measure the construct validity, confirmatory factor analyses were carried out on the structure of the instrument.

As the Multivariate Normality tests indicated that the multivariate distribution of the items was non normal in all of the samples (e.g., 
multivariate kurtosis value $=2543$ and 2538 in the Spanish and Chilean samples, respectively, $p<.001$ ), the parameters of the confirmatory factor analyses were estimated using the method of Weighted Least Squares with LISREL 8.8 software (Jöreskog \& Sörbom, 2004).

This method was used with the polychoric matrix and the asymptotic covariance matrix of the items in the scale. In all estimated models, the effect codification method proposed by Little, Slegers, and Card (2006) was used, in order to identify and set the scale of latent variables. This requires the set of indicator averages to be made equal to 0 , and the set of factor loadings for a construct to have an average of 1 , which is the same as making its sum equal to the number of indicators. According to Little and collaborators, this method is best suited for confirming the factor structure of a construct based on particular items.

Following the recommendations of $\mathrm{Hu}$ and Bentler (1999) for Maximum Likelihood models obtained in large samples $(N>250)$, goodness of fit was assessed by the comparative fit index (CFI; values of .95 or greater indicate that the model adequately fits the data), the non-normed fit index (NNFI; values of .95 or greater indicate that the model adequately fits the data). The root mean squared error of approximation (RMSEA; values of .06 or less indicate that the model adequately fits the data), and the stand- ardized root mean square residual (SRMR; values of .08 or less indicate a good fit).

The average variance extracted (AVE) was also calculated; values higher than .50 are considered adequate by Fornell \& Larcker (1981) and the composite reliability coefficient (CR); values higher than .70 are considered optimal by Gefen and Straub (2005).

\section{Results}

\section{Descriptive data and internal con- sistency of the scale}

Results obtained in the Spanish sample indicate that the average degree of application of AC total was medium-high, reaching a value of $2.88(S D=.45)$ out of a possible range of 1-4. In the values acquired in the Chilean sample, it is observed that the average percentage of total AC application was also medium-high, but somewhat higher than the result obtained in the Deusto sample, reaching a value of 3.18 $(S D=.43)$.

Both at Deusto and Temuco, the dimensions better implemented were interaction ( $M_{\text {Deusto }}=3.15$, $\left.S D=.54 ; M_{\text {Temuс }}=3.33, S D=.57\right)$ and heterogeneity $\left(M_{\text {Deusto }}=3.1\right.$, $\left.S D=.57 ; M_{\text {тетисо }}=3.33, S D=.49\right)$ and the least implemented was group reflection $\left(M_{\text {Deusto }}=2.64\right.$, $S D=.57 ; M_{\text {Tетисо }}=2.96, S D=.57$ ). Nevertheless, both in the evaluation of the total AC and of each dimen- 
sion as an independent item, the Temuco values sample were slightly higher than the Deusto sample ex-

cept for item 44 pertaining to the positive interdependence dimension (Table 1).

Table 1

Descriptive Features Analysis of the Dimensions of the Scale

\begin{tabular}{|c|c|c|c|c|c|c|c|c|}
\hline \multirow{2}{*}{$\begin{array}{l}\text { Sample } \\
\text { Assessment }\end{array}$} & \multicolumn{4}{|c|}{ Deusto } & \multicolumn{4}{|c|}{ Temuco } \\
\hline & $M$ & $S D$ & As & $K$ & $M$ & $S D$ & As & $K$ \\
\hline 55. & 2.53 & .98 & -.09 & -1.00 & 2.88 & .90 & -.49 & -.48 \\
\hline 47. & 2.58 & .98 & -.12 & -.98 & 2.80 & .85 & -.40 & -.38 \\
\hline 13. & 2.74 & .83 & -.32 & -.38 & 3.06 & .89 & -.69 & -.29 \\
\hline 26. & 2.91 & .86 & -.58 & -.19 & 3.12 & .88 & -.82 & -.04 \\
\hline 42. & 3.23 & .80 & -.92 & .46 & 3.55 & .69 & -1.60 & 2.33 \\
\hline 34. & 3.34 & .77 & -1.06 & .67 & 3.68 & .61 & -2.17 & 5.27 \\
\hline Total & 2.89 & .58 & -.43 & .24 & 3.19 & .49 & -.74 & .55 \\
\hline Heterogeneity & $M$ & $S D$ & As & $K$ & $M$ & $S D$ & As & $K$ \\
\hline 27. & 3.00 & .74 & -.63 & .52 & 3.32 & .70 & -.81 & .41 \\
\hline 19. & 3.10 & .74 & -.69 & .58 & 3.34 & .71 & -.86 & .40 \\
\hline 11. & 3.14 & .73 & -.60 & .23 & 3.31 & .78 & -.93 & .29 \\
\hline 35. & 3.15 & .74 & -.70 & .41 & 3.37 & .75 & -.95 & .25 \\
\hline Total & 3.1 & .57 & -.63 & .58 & 3.33 & .49 & -.86 & 1.10 \\
\hline Social Skills & $M$ & $S D$ & As & $K$ & $M$ & $S D$ & As & $K$ \\
\hline 17. & 2.36 & .92 & .03 & -.87 & 2.61 & .9 & -.10 & -.77 \\
\hline 12. & 2.53 & .86 & -.18 & -.61 & 3.04 & .82 & -.63 & -.00 \\
\hline 20. & 2.79 & .85 & -.39 & -.39 & 3.26 & .80 & -.97 & .51 \\
\hline 48. & 2.86 & .79 & -.52 & .03 & 3.27 & .73 & -.80 & .37 \\
\hline 43. & 3.03 & .80 & -.59 & -.01 & 3.36 & .70 & -.97 & .89 \\
\hline 36. & 3.07 & .78 & -.68 & .28 & 3.36 & .73 & -.98 & .52 \\
\hline 28. & 3.10 & .78 & -.72 & .31 & 3.38 & .72 & -1.05 & .85 \\
\hline Total & 2.82 & .55 & -.51 & .44 & 3.17 & .61 & -.73 & 25 \\
\hline Interaction & $M$ & $S D$ & As & $K$ & $M$ & $S D$ & As & $K$ \\
\hline 56. & 3.08 & .85 & -.79 & .15 & 3.38 & .74 & -1.16 & 1.24 \\
\hline 37. & 3.12 & .77 & -.65 & .12 & 3.38 & .72 & -.99 & .59 \\
\hline 21. & 3.28 & .74 & -.93 & .75 & 3.54 & .66 & -1.41 & 1.94 \\
\hline 29. & 3,34 & ,60 &,- 78 &, 59 & 3,55 & .66 & $-1,50$ & 2.29 \\
\hline Total & 3.15 & .54 & -.69 & .58 & 3.33 & .57 & -.83 & .37 \\
\hline
\end{tabular}


DESIGN AND VALIDATION OF THE

\begin{tabular}{|c|c|c|c|c|c|c|c|c|}
\hline \multirow{2}{*}{$\frac{\text { Sample }}{\text { Positive Interdependence }}$} & \multicolumn{4}{|c|}{ Deusto } & \multicolumn{4}{|c|}{ Temuco } \\
\hline & $M$ & $S D$ & As & $K$ & $M$ & $S D$ & As & $K$ \\
\hline 49. & 2.53 & .93 & -.11 & -.86 & 2.59 & .92 & -.15 & -.79 \\
\hline 38. & 2.56 & .91 & -.13 & -.77 & 2.95 & .90 & -.52 & -.52 \\
\hline 30. & 2.71 & .87 & -.32 & -.52 & 3.05 & .85 & -.62 & -.22 \\
\hline 51. & 2.89 & .88 & -.50 & -.37 & 3.19 & .86 & -.83 & -.08 \\
\hline 44. & 2.93 & .85 & -.55 & -.23 & 2.83 & .87 & -.49 & -.33 \\
\hline 53. & 3.01 & .78 & -.61 & .19 & 3.36 & .68 & -.89 & .77 \\
\hline 45. & 3.01 & .83 & -.67 & .08 & 3.31 & .75 & -.93 & .51 \\
\hline 18. & 3.10 & .77 & -.71 & .35 & 3.39 & .76 & -1.22 & 1.20 \\
\hline 22. & 3.57 & .70 & -1.62 & 2.21 & 3.70 & .61 & -2.26 & 5.43 \\
\hline Total & 2.92 & .52 & -.58 & .75 & 3.19 & .52 & -.75 & .58 \\
\hline Group Reflection & $M$ & $S D$ & As & $K$ & $M$ & $S D$ & As & $K$ \\
\hline 15. & 2.40 & .96 & .09 & -.94 & 2.68 & .95 & -.217 & -.88 \\
\hline 23. & 2.55 & .92 & -.14 & -.81 & 2.85 & .83 & -.402 & -.31 \\
\hline 50. & 2.59 & .88 & -.17 & -.67 & 2.95 & .84 & -.500 & -.31 \\
\hline 14. & 2.60 & .91 & -.18 & -.75 & 3.02 & .85 & -.564 & -.31 \\
\hline 39. & 2.74 & .85 & -.33 & -.44 & 3.04 & .84 & -.640 & -.14 \\
\hline 31. & 2.76 & .84 & -.40 & -.33 & 3.12 & .83 & -.735 & .00 \\
\hline 16. & 2.86 & .85 & -.48 & -.27 & 3.07 & .83 & -.650 & -.09 \\
\hline Total & 2.64 & .57 & -.36 & -.22 & 2.96 & .57 & -.41 & .05 \\
\hline Tutoring & $M$ & $S D$ & As & $K$ & $M$ & $S D$ & As & $K$ \\
\hline 32. & 2.64 & .90 & -.20 & -.98 & 3.12 & .90 & -.77 & -.25 \\
\hline 57. & 2.64 & .91 & -.23 & -.74 & 2.88 & .86 & -.44 & -.42 \\
\hline 54. & 2.76 & .87 & -.36 & -.49 & 3.16 & .81 & -.75 & .09 \\
\hline 24. & 2.82 & .93 & -.37 & -.73 & 3.27 & .77 & -.77 & -.06 \\
\hline 52. & 2.84 & .88 & -.40 & -.53 & 3.14 & .82 & -.73 & .00 \\
\hline 46. & 2.92 & .88 & -.46 & -.53 & 3.13 & .83 & -.73 & -.06 \\
\hline 40. & 3.21 & .83 & -.90 & .28 & 3.48 & .74 & -1.41 & 1.48 \\
\hline Total & 2.83 & .67 & -.47 & -.20 & 3.18 & .51 & -.69 & .54 \\
\hline
\end{tabular}

The internal consistency of the scale was assessed through Cronbach's Alpha coefficient, which displayed a result of .95 for the total sample and .94 for each of the samples, both from the Spanish sample and from the Chilean sample (Table 2).

The consistency of the CLAS dimensions was also high, with the tutoring dimension showing a higher reliability in the total sample 
Table 2

Analysis of the Internal Consistency of the Dimensions Composing CLAS

\begin{tabular}{lccc}
\hline \multicolumn{1}{c}{ CLAS } & $\begin{array}{c}\alpha \\
\text { Total } \\
N=1470\end{array}$ & $\begin{array}{c}\alpha \\
\text { Deusto } \\
n=686\end{array}$ & $\begin{array}{c}\alpha \\
\text { Temuco } \\
n=784\end{array}$ \\
\hline Group Reflection & .79 & .77 & .79 \\
Social Skills & .80 & .79 & .77 \\
Tutoring & .88 & .87 & .86 \\
Assessment & .73 & .73 & .70 \\
Positive Interdependence & .80 & .81 & .78 \\
Heterogeneity & .79 & .78 & .78 \\
Interaction & .72 & .70 & .70 \\
Total & .95 & .94 & .94 \\
\hline
\end{tabular}

(.88) and in the samples of Deusto $(.87)$ and Temuco $(.86)$ respectively. Interaction is the dimension that has a lower reliability, being adequate in both cases, for the total sample (.72) and for each of the sub-samples $(.70$ for Deusto and .70 for Temuco).

The Split Half Method was applied, which yielded an Alpha Coefficient result of .89 in the Deusto sample and .90 in the Temuco sample for the first part, and .90 in both samples for the second part. The Spearman-Brown coefficient was .90 in the Deusto sample and .91 in the Temuco sample.

\section{Construct validity}

Firstly, the theoretical model was tested for each sample (Table 3). This model comprised 7 factors (positive interdependence, interaction, social skills, group reflection, assessment, heterogene- ity and tutoring). The outcome was satisfactory, as it showed excellent fit indexes both in the Spanish sample, $\chi^{2}(881, n=686)=1921.35$ $p<.001$; RMSEA $=.042(95 \%$ CI: $.039 ; .044), \mathrm{CFI}=1, \mathrm{NNFI}=1$, SRMR $=.08$, and in the Chilean sample, $\chi^{2}(881, n=784)=1883.15$, $p<.001$; RMSEA $=.041(95 \%$ CI: $.038 ; .043), \mathrm{CFI}=1, \mathrm{NNFI}=1.00$, $\mathrm{SRMR}=.07$.

An alternative model consisting of one factor was estimated, which displayed some poor fit indexes, $\chi^{2}(902, n=686)=2164$, $p<.001$; RMSEA $=.045(95 \% \mathrm{CI}$ : $.043 ; .048), \mathrm{CFI}=.89, \mathrm{NNFI}=.88$, $\mathrm{SRMR}=.11$, as in the Chilean sample, $\chi^{2}(902, n=784)=2025$, $p<.001$; RMSEA $=.044$ (95\% CI: $.043 ; .047), \mathrm{CFI}=.90, \mathrm{NNFI}=.89$, $\mathrm{SRMR}=.10$.

Finally, a seven-factor model in which the factors were specified as uncorrelated was also es- 
DESIGN AND VALIDATION OF THE

Table 3

Structural Models of the CLAS on the Basis of a Confirmatory Factor Analysis

\begin{tabular}{clccccccc}
\hline Models & \multicolumn{1}{c}{ Sample } & $\chi^{2}$ & CFI & NNFI & SRMR & RMSEA & [95\% CI] \\
\hline \multirow{2}{*}{ One factor } & $\begin{array}{l}\text { Spanish Sample } \\
(686)\end{array}$ & 2164 & .89 & .88 & .11 & .045 & .043 & .048 \\
& $\begin{array}{l}\text { Chilean Sample } \\
\text { (784) }\end{array}$ & 2025 & .90 & .89 & .10 & .044 & .043 & .047 \\
& $\begin{array}{l}\text { Spanish Sample } \\
\text { (686) }\end{array}$ & 7825 & .40 & .38 & .26 & .11 & .10 & .11 \\
$\begin{array}{c}\text { Seven } \\
\text { uncorrelatedfactors }\end{array}$ & $\begin{array}{l}\text { Chilean Sample } \\
\text { (784) }\end{array}$ & 7615 & .45 & .44 & .23 & .10 & .09 & .11 \\
& $\begin{array}{l}\text { Spanish Sample } \\
(686)\end{array}$ & 1921,35 & 1 & 1 & .080 & .042 & .039 & .044 \\
$\begin{array}{l}\text { Seven correlated } \\
\text { factors }\end{array}$ & $\begin{array}{l}\text { Chilean Sample } \\
\text { (784) }\end{array}$ & 1883.15 & 1 & 1 & .069 & .041 & .038 & .043 \\
& $\begin{array}{l}\text { Both samples } \\
\text { (1470) }\end{array}$ & 4071 & .99 & .99 & .069 & .042 & .041 & .044 \\
\hline
\end{tabular}

timated. For this orthogonal model all the fit indexes were poor, $\chi^{2}(902, n=686)=7825$, $p<.001 ;$ RMSEA $=.11(95 \% \mathrm{CI}$ : $.10 ; .11), \mathrm{CFI}=.40, \mathrm{NNFI}=.38$, SRMR $=.26$, as in the Chilean sample, $\chi^{2}(902, n=784)=7615$, $p<.001 ;$ RMSEA $=.10(95 \% \mathrm{CI}:$ $.09 ; .11), \mathrm{CFI}=.45, \mathrm{NNFI}=.44$, $\mathrm{SRMR}=.23$.

Consequently, the seven-correlated-factors model is selected as it is considered better fit. The next step was to evaluate the factor invariance of the questionnaire across Chilean and Spanish students using multiple-group-covariance-structure analysis. First, the configural in- variance of the model was tested to demonstrate that the pattern of fixed and free parameters was equivalent across samples, $\chi^{2}(1762$, $N=1470)=4071$, RMSEA $=.042$ $(95 \%$ CI: .041; .044), NNFI $=.99$, $\mathrm{CFI}=.99$ and $\mathrm{SRMR}=.07$.

The invariance of the factor loadings was then tested. The nonsignificant $\chi^{2}$ increment indicated that the overall pattern of factor loadings was similar across Spanish and Chilean students, $\Delta \chi^{2}(37$, $N=1470)=38, n s$. Finally, the invariance of the variances and covariances of the latent variables was tested. In this case the change in $\chi^{2}$ was also not significant, indicating 
Table 4

Factor Loadings of CLAS Items

\begin{tabular}{|c|c|c|c|}
\hline Dimension & Item & Deusto & Temuco \\
\hline \multirow{6}{*}{ Assessment } & 13. & 0.78 & 0.82 \\
\hline & 26. & 0.78 & 0.91 \\
\hline & 34. & 0.85 & 0.70 \\
\hline & 42. & 0.85 & 0.86 \\
\hline & 47. & 0.75 & 0.65 \\
\hline & 55 & 0.75 & 0.79 \\
\hline \multirow{4}{*}{ Heterogeneity } & 11. & 0.69 & 0.74 \\
\hline & 19. & 0.82 & 0.91 \\
\hline & 27. & 0.82 & 0.91 \\
\hline & 35. & 0.82 & 0.87 \\
\hline \multirow{7}{*}{ Social Skills } & 12. & 0.89 & 0.87 \\
\hline & 20. & 0.79 & 0.74 \\
\hline & 28. & 0.80 & 0.90 \\
\hline & 36. & 0.86 & 0.87 \\
\hline & 43. & 0.91 & 0.89 \\
\hline & 48. & 0.88 & 0.87 \\
\hline & 17. & 0.82 & 0.72 \\
\hline \multirow{4}{*}{ Interaction } & 21 & 0.85 & 0.85 \\
\hline & 29. & 0.81 & 0.85 \\
\hline & 37. & 0.85 & 0.87 \\
\hline & 56. & 0.72 & 0.72 \\
\hline \multirow{9}{*}{$\begin{array}{c}\text { Positive } \\
\text { Interdependence }\end{array}$} & 44. & 0.73 & 0.57 \\
\hline & 18. & 0.72 & 0.75 \\
\hline & 22. & 0.57 & 0.71 \\
\hline & 30. & 0.84 & 0.86 \\
\hline & 38. & 0.80 & 0.69 \\
\hline & 45. & 0.82 & 0.86 \\
\hline & 49. & 0.76 & 0.65 \\
\hline & 51. & 0.81 & 0.86 \\
\hline & 53. & 0.81 & 0.82 \\
\hline \multirow{7}{*}{ Group Reflection } & 15. & 0.72 & 0.74 \\
\hline & 23 & 0.87 & 0.87 \\
\hline & 31. & 0.80 & 0.88 \\
\hline & 39. & 0.73 & 0.82 \\
\hline & 14. & 0.88 & 0.83 \\
\hline & 16. & 0.74 & 0.78 \\
\hline & 50. & 0.88 & 0.89 \\
\hline \multirow{7}{*}{ Tutoring } & 24. & 0.84 & 0.83 \\
\hline & 32. & 0.82 & 0.88 \\
\hline & 40. & 0.82 & 0.80 \\
\hline & 46. & 0.92 & 0.89 \\
\hline & 52. & 0.92 & 0.94 \\
\hline & 54. & 0.91 & 0.94 \\
\hline & 57. & 0.84 & 0.87 \\
\hline
\end{tabular}


DESIGN AND VALIDATION OF THE

Table 5

Composite Reliability Coefficients and Average Variance Extracted

\begin{tabular}{lcccc}
\hline \multicolumn{1}{c}{ Subsample } & \multicolumn{2}{c}{ Deusto } & \multicolumn{2}{c}{ Temuco } \\
\hline \multicolumn{1}{c}{ Dimension } & $C R$ & $A V E$ & $C R$ & $A V E$ \\
\hline Assessment & .91 & .63 & .91 & .63 \\
Heterogeneity & .87 & .62 & .92 & .74 \\
Social skills & .95 & .72 & .94 & .71 \\
Interaction & .88 & .66 & .89 & .68 \\
Positive Interdependence & .93 & .59 & .92 & .58 \\
Reflection & .93 & .65 & .94 & .69 \\
Tutoring & .96 & .75 & .96 & .77 \\
\hline
\end{tabular}

that the overall pattern of variances and covariances was equivalent for Chilean and Spanish students, $\Delta \chi^{2}(28, N=1470)=27, n s$.

Table 4 displays the factor loadings of the items in each scale for each sample. All of them exceed the .40 cutoff points.

The average variance extracted (AVE) was estimated for the factors. In all the cases the AVE values were higher than .50. The composite reliability coefficients (CR) were also calculated, being all values above .80 (Table 5).

\section{Discussion}

In previous research on the implementation of CL in universities, instruments have been used that did not include all the essential elements of this methodology. They had been created ad hoc and had not been validated in the theoretical structure through confirmatory factor analy- sis (Bay \& Çetin, 2012; García et al., 2012; Ghaith, 2002; Ibarra \& Rodríguez, 2007; Johnson \& Johnson, 1983; Johnson et al., 1983).

Thus, the main goal of this study was to elaborate an instrument to measure the degree of application of CL in Higher Education, CLAS. The scale was based on the theoretical dimensions of CL: Positive interdependence, interaction, social skills, group reflection (Johnson, Johnson, \& Smith, 2007). Other important components were added in order to guarantee successful cooperation: Tutoring (García, Traver, \& Candela, 2001), heterogeneity (León del Barco \& Latas-Pérez 2005; Suárez, 2010; Veenman et al., 2000) and assessment (Barkley, Cross, \& Major 2007; Shimazoe \& Aldrich, 2010).

CLAS was applied at two universities with students of different nationalities: Spanish (University of Deusto) and Chilean (Catholic University of Temuco). The instru- 
ment showed a high degree of consistency in the total scale and its dimensions, both for the total sample as for the samples in each country.

The results suggested that the average percentage of AC total application and each of the dimensions is medium-high both at the University of Deusto and the University of Temuco, with slightly higher values obtained in Temuco. Interaction and heterogeneity dimensions acquired the highest values. The reflection dimension obtained the lowest score, around the middle point of the scale. Several studies have examined the positive effect of reflection to promote student learning (Coulson \& Harvey, 2013; Chen, Wei, \& Liu, 2010; Quinton \& Smallbone, 2010). Therefore, it would be desirable to incorporate this aspect in the training of university teachers on cooperative learning.

Although numerous publications indicate that teachers devote insufficient attention to the implementation of these elements (Antil, Jenkins, Wayne, \& Vadasy, 1998; Veenman et al., 2002; Veenman et al., 2000), the results of this study showed a higher application of CL level dimensions by teachers. These differences may be due to the different instruments used for the measurement in the studies. Likewise, the most positive results in this research could be explained by the makeup of the sample, considering that the teachers who volunteered to participate may be more committed to this methodology.

Furthermore, CLAS demonstrated adequate construct validity, tested through confirmatory factor analysis that confirmed a 7-correlated-factors structure. Excellent fit indexes were attained both in the Spanish sample and the Chilean sample. Alternative models, such as a one dimension structure and a seven uncorrelated factor structure, displayed poorer adjustment. The measurement model was invariant for both samples, which reinforces the equivalence of the constructs in both cultures.

Therefore, this study has provided an instrument that is valid and reliable for measuring the application of CL, which marks an important development in research on this methodology in Higher Education.

It would be advisable to improve the validation of the instrument, for example, collating the relationship between its scores and the information gathered from direct classroom observation. It would also be interesting to relate its scores to real student achievement data. Thus, we would have greater assurance of the validity of the instrument and of the benefits that this methodology provides for students' learning and development. 


\section{References}

Antil, L. R., Jenkins, J. R., Wayne, S. K., \& Vadasy, P. F. (1998). Cooperative learning: Prevalence, conceptualizations, and the relation between research and practice'. American Educational Research Journal, 35(3), 419-454. doi: 10.3102/00028312035003419

Aguado, D., Arranz, V., Valera-Rubio, A., \& Marín-Torres, S. (2011). Evaluación de un programa blended-learning para el desarrollo de la competencia trabajar en equipo. Psicothema, 23(3), 356-361.

Ayats, J. C., Zamora, P., \& Desantes, R. (2004). Los empleadores y los titulados de la Universidad Politécnica de Valencia, Actas del XII Congreso Universitario de Innovación Educativa en las Enseñanzas Técnicas. Barcelona.

Barraycoa, J., \& Lasaga, O. (2010). La competencia de trabajo en equipo: Más allá del corta y pega. Vivat Academia, 111, 1-5. Retrieved from: http://pendientedemigracion.ucm.es/ info/vivataca/numeros/n111/PDFs/ Olgacop.pdf

Bay, E., \& Çetin, B. (2012). İşbirliği süreci ölçeği (İSÖ) geliştirilmesi. Uluslararasi Insan Bilimleri Dergisi, 9(1), 1064-1075. Retrieved from: http://www.insanbilimleri.com

Barckley, E. F., Cross K. P., \& Major, C. H. (2007). Técnicas de aprendizaje colaborativo. Madrid: Morata.

Biggs, J., \& Tang, C. (2011). Teaching for quality learning at University: What the student does. Maidenhead: McGraw-Hill. Open University Press. Blackford, P., Kutnik, P., Baines, E., \& Galton, M. (2003). Toward a social pedagogy of classroom assessment.
International Journal of Educational Research, 39, 153-172. doi: 10.1016/ S0883-0355(03)00078-8

Cavanagh, M. (2011). Students' experiences of active engagement through cooperative learning activities in lectures. Active Learning in Higher Education, 12(1), 23-33. doi: $10.1177 / 1469787410387724$

Chen, N. S., Wei, C. W., \& Liu, C. C. (2010). Effects of matching teaching strategy to thinking style on learner's quality of reflection in an online learning environment. Computers \& Education, 56(1), 53-64.

Cohen, E. G. (1994). Restructuring the classroom: Conditions for productive small groups. Review of Educational Research, 64(1), 1-35. doi: 10.3102/00346543064001001

Coulson, D., \& Harvey, M. (2013). Scaffolding student reflection for experience-based learning: A framework. Teaching in Higher Education, 18(4), 401-413, doi: 10.1080/13562517.2012.752726

Fornell, C., \& Larcker, D. F. (1981). Evaluating structural equation models with unobservable variables and measurement error. Journal of Marketing Research, 18(1), 39-50.

García, M. M., González, I., \& Mérida, R. (2012). Validación del cuestionario ACOES. Análisis del trabajo cooperativo en Educación Superior. Revista de Investigación Educativa, 30(1), 87-109.

García, R., Traver, J., \& Candela, I. (2001). Aprendizaje cooperativo. Fundamentos, características y técnicas. Madrid: CCS.

Gefen, D., \& Straub, D. (2005). A practical guide to factorial validity us- 
ing PLS-graph: Tutorial and annotated example. Communications of the AIS, 16(1), 91-109.

Ghaith, G. M. (2002). The relationship between cooperative learning, perception of social support, and academic achievement. System, 30(2), 263-273. doi: 10.1016/S0346-251X(02)00014-3

Gillies, R., \& Boyle, M. (2010). Teachers' reflections on cooperative learning: Issues of implementation. Teaching and Teacher Education, 26(4), 933940. doi: 10.1016/j.tate.2009.10.034

Hammond, J. A., Bithell, C. P., \& Jones, L. (2010). A first year experience of student-directed peer-assisted learning. Active Learning in Higher Education, 11(3), 201-212. doi: $10.1177 / 1469787410379683$

Hancock, D. (2004). Cooperative learning and peer orientation effects on motivation and achievement. Journal of Educational Research, 97(3), 159161. doi: 10.3200/JOER.97.3.159-168

Hijzen, D., Boekaerts, M., \& Vedder, P. (2006). The relationship between the quality of cooperative learning, students' goal preferences, and perceptions of contextual factors in the classroom. Scandinavian Journal of Psychology, 47, 9-21.

Hu, L., \& Bentler, P. M. (1999). Cutoff criterion for fit indexes in covariance structure analysis: Conventional criteria versus new alternatives. Structural Equation Modeling, 6(1), 1-55.

Ibarra, M. ${ }^{\text {a }}$ S., \& Rodríguez, G. (2007). El trabajo colaborativo en las aulas universitarias: Reflexiones desde la autoevaluación. Revista de Educación, 344, 355-375.

Johnson, D. W., \& Johnson, R. T (1983). Social interdependence and perceives academic and personal support in the classroom. The Journal of Psychology, 120, 77-82.
Johnson, D. W. Johnson, R. T., \& Anderson, D. (1983). Social interdependence and classroom climate. The Journal of Psychology, 114, 135-142.

Johnson, D. W., Johnson, R. T., \& Holubec, E. J. (1994). Cooperative learning in the classroom. Alexandria, VA: Association for supervision and curriculum development.

Johnson, D. W., Johnson, R. T., \& Smith, K. A. (2007). The state of cooperative learning in postsecondary and professional settings. Educational Psychology Review, 19(1), 1529. doi: 10.1007/s10648-006-9038-8

Jöreskog, K. G., \& Sörbon, D. (2004). LISREL 8.8 for Windows [Computer Software]. Lincolnwood, IL: Scientific Software International, Inc.

Kagan, S., \& Kagan, M. (1994). The structural approach: Six keys to cooperative. In S. Sharan (Ed.), Handbook of cooperative learning methods (pp. 115-133). Westport, CT: Greenwood Press.

León del Barco, B., \& Latas-Pérez, C. (2007). La formación en técnicas de aprendizaje cooperativo del profesor universitario en el contexto de la convergencia europea. Revista de Psicodidáctica, 12(2), 269-278. doi: 10.1387/RevPsicodidact.224

Little, T. D., Slegers, D. W., \& Card, N. A. (2006). A nonarbitrary method of identifying and scaling latent variables in SEM and MACS models. Structural Equation Modeling, 13, 59-72.

Ovejero, A. (1990). El aprendizaje cooperativo. Una alternativa eficaz a la enseñanza tradicional. Barcelona: PPU.

Peterson, S. E., \& Miller, J. A. (2004). Comparing the quality of students" experiences during cooperative learning and large-group instruction. The Journal of Educational Research, 97(3), 123-133. 
Prieto, L. (2007). El aprendizaje cooperativo. Madrid: PPC.

Quinton, S., \& Smallbone, T. (2010). Feeding forward: Using feedback to promote student reflection and learning - a teaching model. Innovations in Education and Teaching International, 47(1), 125-135. doi: 10.1080/14703290903525911

Shimazoe, J., \& Aldrich, H. (2010). Group work can begratifying: Understanding and overcoming resistance to cooperative learning. College Teaching, 58, 52-57. doi: 10.1080/ 87567550903418594

Slavin, R. E. (1990). Cooperative learning. Theory, research, and practice. Needham Heights, MA: Allyn and Bacon.

Suárez, C. (2010). Cooperación como condición social de aprendizaje. Barcelona: UOC.

Vargas, F. (2006). De las virtudes laborales a las competencias clave: Un nuevo concepto para antiguas demandas. Politécnica, 3, 13-26.

Veenman, S., Benthum. N., Bootsma, D., Dieren, J., \& Kemp, N. (2002). Cooperative learning and teacher education. Teaching and Teacher Education, 18(1), 87-103. doi: 10.1016/ S0742-051X(01)00052-X

Veenman, S., Kenter, B., \& Post, K. (2000). Cooperative learning in Dutch primary classrooms. Educational Studies, 26(3), 281-302.

Zubimendi, J. L., Ruiz, M. P., Carrascal, E., \& de la Presa, H. (2010). El aprendizaje cooperativo en el aula universitaria: Manual de ayuda al profesorado. Publicaciones de la Universidad del País Vasco. Retrieved from: http://www.industriaingeniaritza-tekniko-bilbao.ehu.es/ p229-content/es/contenidos/noticia/ euiti_aprendizaje/es_noticia/ adjuntos/aprendizaje_cooperativo_ aula_universitaria.pdf

Cristina Atxurra, is a lecturer in the Department of Didactics and Curriculum Development, Faculty of Psychology and Education, University of Deusto. She is a member of the research team on Competences and Values Development. Her focus areas are active methodologies for competence development.

Lourdes Villardón-Gallego, $\mathrm{PhD}$, is a lecturer on Didactics and Curricular Development, Faculty of Psychology and Education, University of Deusto. She coordinates the Competences and Values Development research team, which has been recognized by the Basque University System (2007, 2009 and 2012). She has published extensively on teaching methodologies for development of competences in Higher Education and has extensive experience in training teaching staff in this field.

Esther Calvete, $\mathrm{PhD}$, is a lecturer on Psychology at the University of Deusto. She coordinates the Deusto Stress Research team. Her focus areas include the development of depression and aggressive behavior in adolescents. 


\section{Appendix}

\section{Cooperative Learning Application Scale, CLAS}

1. The members of my group have skills and abilities that complement each other.

2. The lecturer teaches us to properly manage in-group situations.

3. In this subject students receive the grades they deserve, no more, no less.

4. The lecturer helps us identify and define the difficulties in group work.

5. During the lesson we have time to reflect on our ways of working in the group and how to improve.

6. In this subject the lecturer proposes activities which encourage individual reflection on learning.

7. The lecturer provides us with guidelines to solve conflicts that might arise in the group.

8. In this subject, each group member has to make an effort in order to help the group achieve their results.

9. Group members have different capabilities that facilitate the completion of the task.

10. In this subject, one of the goals is to learn how to engage with others.

11. In this subject, we have the opportunity to share our opinions with group members.

12. The better each group member carries out their task, the better the group's grades will be.

13. The lecturer provides us with tools for us to reflect on how we are working in the group.

14. As we work, we receive feedback from the lecturer in order to improve.

15. In this subject, the evaluation system is fair.

16. In our group we have a diversity of views, which helps us in our learning.

17. In this subject, respect in group relationships is encouraged.

18. This subject allows me to interact with my fellow group members.

19. In this subject, when we work in groups, we have to make sure that we all learn.

20. In our group we assess the performance of each one of us and we provide guidelines for improvement.

21. The lecturer oversees group work as we carry it out.

22. If we work hard in this subject, we can achieve very good grades. 
23. Group members are diverse in a number of ways, which enriches us.

24. This subject encourages us to freely express our points of view.

25 . In this subject, interaction with my fellow group members is necessary in order to carry out the task.

26. When we work in groups our grades depend on how much all members have learnt.

27. All the group members together, we identify which actions help the group and which don't.

28. During group work, the lecturer is available to answer our questions.

29. In these lessons we all have the opportunity to achieve good results/grades if we put our minds to it.

30. This subject creates opportunities for us to interact with others.

31. In this subject I need the help of my fellow group members in order to fulfill the task.

32. When we work in groups, each member has a task to contribute to.

33. The lecturer intervenes when we need it in order to ensure that we make progress in our group task.

34. In this subject the evaluation system for group work prevents skiving.

35. In this subject we exercise our social skills.

36. When we work in groups, we can't fulfill a task unless everybody contributes.

37. The lecturer helps us determine the level of efficiency at which the group has performed.

38. When we work in groups, we need the ideas of all of us in order to achieve success.

39. The lecturer guides us and helps us with our group task.

40. When we work in groups, we have to share materials or information in order to complete the task.

41. The lecturer motivates us to make progress in our group task.

42. The assessment system for this subject takes into account the individual contributions of each team member to the group work.

43. In this subject we communicate and share information with fellow group members through diverse media (face-to-face, online...).

44. The lecturer monitors the tasks fulfilled by the group and each of the group members, and helps us improve. 
